\title{
Academe-Industry Partnership: Basis for Enhanced Learning of BSBA Students in One State University
}

\author{
Ma. Jamine J. De Guman \\ Business Administration Program, Pangasinan State University, Lingayen Campus, Philippines
}

Received August 17, 2020; Revised October 16, 2020; Accepted October 24, 2020

\section{Cite This Paper in the following Citation Styles}

(a): [1] Ma. Jamine J. De Guman, "Academe-Industry Partnership: Basis for Enhanced Learning of BSBA Students in One State University," Universal Journal of Educational Research, Vol. 8, No. 12, pp. 6574-6584, 2020. DOI: 10.13189/ujer.2020.081222.

(b): Ma. Jamine J. De Guman (2020). Academe-Industry Partnership: Basis for Enhanced Learning of BSBA Students in One State University. Universal Journal of Educational Research, 8(12), 6574-6584. DOI: 10.13189/ujer.2020.081222.

Copyright $\bigcirc 2020$ by authors, all rights reserved. Authors agree that this article remains permanently open access under the terms of the Creative Commons Attribution License 4.0 International License

\begin{abstract}
Academe-industry partnership is critical to delivering a holistic learning experience for college students. Employing the descriptive-correlational quantitative method of research, the study aims to assess the level of implementation of the internship program within the university and the industry partner, the student interns' feedback on the industry partners, the level of attainment of internship objectives and the problems encountered during the internship period, through the use of a constructed survey questionnaire. The researcher has determined that the internship program is fully implemented within the campus and the industry partner. Using Pearson correlation coefficient analysis, it was found that the level of implementation of the internship program within the industry partner is correlated with the students' feedback, level of attainment of internship objectives, and the seriousness of problems encountered. The level of implementation positively impacts the level of attainment of objectives and the seriousness of problems encountered. However, level of implementation positively correlated with the students' feedback in terms of collaboration and teamwork, communication, people management, and work ethics. It was found to be negatively associated in terms of their feedback of industry partners' support in decision making and empowerment.
\end{abstract}

Keywords Academe-Industry Partnership, University Industry Collaboration, Internship Program Implementation, Industry Partner Evaluation

\section{Introduction}

Partnerships are essential for educational institutions to minimize its dependence on physical resources, facilitate training and employment for its students, match their curricular offerings to the needs of the industry, and maintaining a reputable image. Industries maintained partnerships with educational institutions as a means to train students to be one of their possible employees in the future. One form of partnership in which both academe and industry collaborate is through internship.

Internship provides the students with opportunities to complement and practice what they have learned in the classroom, gain a greater understanding of the industries' requirements, test career choices, and develop important hands-on workplace skills through the acquisition of practical knowledge and desirable attitudes in recognized host training establishments. [1][2]

The benefits of internship in developing students has been argued and supported in various studies. Advantages of internships for students increased career opportunity, higher salaries, quicker job offers, faster promotion rates, job satisfaction, ease of transition from college to work, better communication skills, working, and applying the knowledge gained from the classroom [3][4] Through internship, the students can reportedly enhance competence in several generic areas of management, including leadership, human resources, oral and written communication, interpersonal communication, problem solving, teamwork, planning and decision-making [1][5]. This leads to higher chances of employability upon 
graduation as getting employed is highly dependent on qualifications sought by the labor market. [6]

The Commission on Higher Education (CHED) requires higher educational institutions to establish strong academic linkages with business, industry and duly recognized government and non-government organizations to promote and provide students with competitive skills and attitudes for employment. [2] It was asserted that higher education institutions (HEI) in the Philippines are immersed in formal, mostly continuing and long-term academe-industry collaboration across various fields of study; funding was asymmetric with the HEI mostly shouldering the cost for partnership. [7] A vast majority of the HEIs had mostly formal type of partnership, with a legally binding agreement where the parties involved concur to share liabilities and responsibilities. [7][8] Internships provide benefits for colleges and universities. The institution builds a tie- up with companies that may eventually employ their graduates by offering on- the- job training opportunities and come up with proposed updates to the curriculum to satisfy the requirements of industry. [9]

Industry is a classification that refers to groups of companies that are related based on their primary business activities. They produce goods or selected services within an economy. [2] Various studies have cited the benefits of school relationship with industry, such as first choice of best students, best selection of future employees, better hiring decisions, exposure to new ideas, creating a network to colleges, fulfilling social responsibilities and receiving part-time help. [4][10]

Despite the benefits brought about by internship from to various stakeholders, there are also various issues that students encounter during internship. These problems include financial constraints, inadequate knowledge and skills, distance of cooperating firm, lack of self-confidence, conflict with other interns, workplace accident, and uncooperative supervisor among others. [11][12] Problems encountered during internships negatively influences the students' attitudes toward jobs within the scope of the students' course, consequently this undermines their intention to work within their course's intended career path in the future. [13]

Following the thrust to strengthen Philippine quality assurance systems in higher educational institutions, [14], the Pangasinan State University implemented the ISO 9001:2015, building a culture of quality across all areas of operation within the university and upgrading higher educational curricular offerings to international standards. [15] The curriculum of the BS Business Administration program of Pangasinan State University-Lingayen Campus culminates in the Practicum/Work Integrated Learning requiring would-be graduating students to render 400 hours of internship in different host training establishments partnered with the Campus. The University formalizes its partnership with the host training establishment through a Memorandum of Agreement which stipulates and outlines the roles and responsibilities of both parties during the course of the intern's training period. It is expected that by the end of the on-the-job training, the student must have developed an understanding of the career area duties and responsibilities and learned the skills they need to be successful in their field of specialization.

This study is primarily aimed at assessing the current state of the implementation of the internship program and drawing some feedback from students with regards to their experiences during the internship along with the problems that they encountered. The purpose is to improve the internship program of Business Administration course in the campus, drawi insights from the results and improve its collaborative partnership with industry partners assuring that the graduates of the program reap the maximum benefits of their on-the-job training.

\section{Statement of the Problem}

This study aimed to (1) determine the profile of the student-interns; (2) identify the profile of the industry partners; (3) ascertain the level of implementation within the university and the industry partner; (4) determine students' feedback on the industry partner with regards to collaboration and teamwork, communication, people management, decision making and empowerment, and work ethics; (5) identify the level of attainment of internship program objectives; (6) determine the seriousness of problems encountered during internship; and (7) determine the relationship between the level of implementation of internship program, students' feedback on industry partner, attainment of internship objectives, and seriousness of problems encountered.

\section{Significance of the Study}

The results of the study shall serve as a guide on how to develop and improve the partnership, identify which of the roles and responsibilities of university and the industry partner lack, provide inputs for both the school and industry partner on how to better improve the welfare of students during internship, and minimize the problems encountered by the interns during the training period. This will also help the university in determining what kind of industry partners would be the best collaborative partner in imparting knowledge and skills to the students. From the perspective of the industry partner, it will help improve their standing within the academic community as a reputable host training establishment that develops students into becoming competent employees in the future.

\section{Research Methodology}

The researcher adopted the quantitative-descriptive method of research and conveniently sampled the students of BS Business Administration program in Lingayen Campus who have recently undertaken internship. The 
survey questionnaire was constructed by the researcher by sampling various documents and studies. The implementation of internship program was taken from the objectives and obligations of HEIs and industry partners outlined in CHED Memorandum Order 23, s. 2009 [16]. Students' feedback and problems that students encountered were adapted from An and Mauhay while the internship program objectives were taken from the program's training plan. [12] The survey questionnaire was enriched and modified to fit the students of the campus' Business Administration program.

\section{Sources of Data and Processing}

The respondents answered the survey through Google forms with the link provided to the students' digital networks. There are 112 unique students who took the survey. Using Microsoft Excel, the data was cleared of double entries and considered the first response of the student-intern. Entries from students who have not yet taken their training were also removed from the data set. Data standardization was conducted on address of the students and their assigned industry partners. The researcher only considered the city/municipality contained in the address string in qualifying location matching between the address of the student and industry partner. Since the department/section names to which interns are assigned to vary from one industry partner to another, the researcher classified the work performed under the assigned department and determined under which value chain activity [17] does the work performed fall under. This was done to standardize the unit or department to which the intern was assigned. Upon validating the integrity of the data, it was exported to IBM SPSS for analysis.

\section{Statistical Treatment Used}

The data gathered from the respondents were interpreted by the following statistical tools. To determine the profile of the respondents and industry partners, frequency, percentage, and mean were used. Weighted means were then employed to determine the level of implementation of internship program within PSU and industry partners, students' feedback on industry partners, level of attainment of internship program objectives, and the seriousness of problems encountered during internship. The weighted mean for the level of implementation was analyzed using the following scale:

Table 1. Likert-scale rating for the level of implementation of internship programs

\begin{tabular}{ccc}
\hline Scale & Range & Interpretation \\
\hline 4 & $3.51-4.00$ & Fully Implemented \\
3 & $2.51-3.50$ & Implemented \\
2 & $1.51-2.50$ & Partially Implemented \\
1 & $1.00-1.50$ & Not Implemented \\
\hline
\end{tabular}

The weighted mean for the students' feedback on industry partners was analyzed using the following scale:

Table 2. Likert-scale rating for the students' feedback on industry partners

\begin{tabular}{ccc}
\hline Scale & Range & Interpretation \\
\hline 5 & $4.51-5.00$ & Strongly Agree \\
4 & $3.51-4.50$ & Agree \\
3 & $2.51-3.50$ & Neither Agree nor Disagree \\
2 & $1.51-2.50$ & Disagree \\
1 & $1.00-1.50$ & Strongly Disagree \\
\hline
\end{tabular}

For the interpretation of the level of attainment of internship objectives, the following scale was used:

Table 3. Likert-scale rating for the level of attainment of internship program objectives

\begin{tabular}{ccc}
\hline Scale & Range & Interpretation \\
\hline 5 & $4.51-5.00$ & Very Highly Attained \\
4 & $3.51-4.50$ & Highly Attained \\
3 & $2.51-3.50$ & Moderately Attained \\
2 & $1.51-2.50$ & Lowly Attained \\
1 & $1.00-1.50$ & Not Attained \\
\hline
\end{tabular}

To interpret the seriousness of problems encountered by the students, the following scale was used:

Table 4. Likert-scale rating for the problems encountered during internship

\begin{tabular}{ccc}
\hline Scale & Range & Interpretation \\
\hline 4 & $3.51-4.00$ & Always a Problem \\
3 & $2.51-3.50$ & Sometimes a Problem \\
2 & $1.51-2.50$ & A Problem \\
1 & $1.00-1.50$ & Not a Problem \\
\hline
\end{tabular}

Pearson correlation analysis was conducted to test the relationship between the level of implementation, the students' feedback on industry partners, level of attainment of internship objectives, and the seriousness of problems encountered. A correlation matrix was created to present the results of the analysis conducted.

\section{Results and Discussion}

Table 5 presents the profile of the student trainee respondents. The mean age of the respondents is 22.87 with $\mathrm{SD}=2.70$. Many students (57.14\%) are below the mean age while the rest $(42.86 \%)$ are above the mean. A quarter of the students $(25.00 \%)$ are male, and three-quarters $(75.00 \%)$ are female. A third of the cities and municipalities of Pangasinan is represented in terms of the students' address. The top three municipalities/city of resident for the students are Lingayen (25\%), Binmaley (12.50\%), and Dagupan City $(9.82 \%)$. The average monthly income for a family of the student intern was found to be at 10,723.16 
with $\mathrm{SD}=8010.90 .61 .61 \%$ of the respondents earn below the average family income, while $23.21 \%$ earn above the mean family income. $15.18 \%$ of the students did not provide any response.

Table 5. Profile of the Student-Trainees

\begin{tabular}{|c|c|c|c|}
\hline Variables & Categories & Frequency & Percentage \\
\hline \multirow{2}{*}{ Age } & Below Mean & 64 & 57.14 \\
\hline & Above Mean & 48 & 42.86 \\
\hline \multirow{2}{*}{ Gender } & Male & 28 & 25.00 \\
\hline & Female & 84 & 75.00 \\
\hline \multirow{16}{*}{$\begin{array}{c}\text { Municipality } \\
\text { or City of } \\
\text { Residence }\end{array}$} & Aguilar & 10 & 8.93 \\
\hline & Bayambang & 1 & 0.89 \\
\hline & Binmaley & 14 & 12.50 \\
\hline & Bolinao & 7 & 6.25 \\
\hline & Bugallon & 10 & 8.93 \\
\hline & Burgos & 4 & 3.57 \\
\hline & Calasiao & 2 & 1.79 \\
\hline & Dagupan City & 11 & 9.82 \\
\hline & Dasol & 3 & 2.68 \\
\hline & Labrador & 5 & 4.46 \\
\hline & Lingayen & 28 & 25.00 \\
\hline & Mangaldan & 7 & 6.25 \\
\hline & Mangatarem & 3 & 2.68 \\
\hline & San Fabian & 3 & 2.68 \\
\hline & Santa Barbara & 3 & 2.68 \\
\hline & Sual & 1 & 0.89 \\
\hline \multirow{3}{*}{$\begin{array}{l}\text { Income } \\
\text { Group }\end{array}$} & Below Mean & 69 & 61.61 \\
\hline & Above Mean & 26 & 23.21 \\
\hline & $\begin{array}{l}\text { Invalid } \\
\text { Values }\end{array}$ & 17 & 15.18 \\
\hline \multirow{4}{*}{$\begin{array}{c}\text { Unit or } \\
\text { Department } \\
\text { Assigned }\end{array}$} & $\begin{array}{c}\text { Firm } \\
\text { Infrastructure }\end{array}$ & 52 & 46.43 \\
\hline & $\begin{array}{c}\text { Human } \\
\text { Resources }\end{array}$ & 4 & 3.57 \\
\hline & Operations & 42 & 37.50 \\
\hline & Services & 12 & 10.71 \\
\hline
\end{tabular}

In terms of the unit or department to which the intern was assigned within the industry partner, $46.43 \%$ of the student-trainees were assigned to department whose activities are considered a part of the firm infrastructure. This is followed by Operations with $37.50 \%$, Services with $10.71 \%$ and Human Resources with $3.57 \%$.

As shown in Table 6, there are a total of seventeen unique industry partners to which the student trainees have been deployed. Over three quarters of the industry partners are either located in Lingayen (47.06\%) or Dagupan City (29.41\%), while the rest are located in Aguilar, Baguio City, Dasol and Lingayen. Over three quarters are classified as government institutions $(76.47 \%)$, while the rest $(23.53 \%)$ are business/commercial establishments. The average length of operation of the industry partners is 55.59 years. The majority of them (52.94\%) have been around for more than the average length of operation while eight (47.06\%) have been operating for less than the average. The level of implementation of internship program in the campus as perceived by the student interns is presented in Table 3.
Table 6. Profile of the Industry Partners

\begin{tabular}{cccc}
\hline Variables & Categories & Frequency & Percentage \\
\hline \multirow{4}{*}{ Location } & Aguilar & 1 & $5.88 \%$ \\
& Alaminos City & 1 & $5.88 \%$ \\
& Baguio City & 1 & $5.88 \%$ \\
& Dagupan City & 5 & $29.41 \%$ \\
& Dasol & 1 & $5.88 \%$ \\
Type of & Lingayen & 8 & $47.06 \%$ \\
Establishment & Business/Commercial & 4 & $23.53 \%$ \\
& Establishment & & \\
\hline Years of & Government & 13 & $76.47 \%$ \\
Operation & Institution & 8 & $47.06 \%$ \\
\hline
\end{tabular}

The results in Table 7 indicate that the internship program is fully implemented within the university. This means that all of the necessary processes and deliverables on the part of the university are fulfilled from the perspective of the students. Before the students are deployed, they are given assistance from the internship instructor in finding industry partners and completing requirements needed for deployment and provided pre-internship orientation before being deployed. During the internship, the students are regularly visited and monitored and assessed for their performance. Upon the culmination of the internship program, the students attend post-internship seminar organized by the Business Administration department. The university incurred the highest weighted mean in the area of provision of pre-internship orientation prior to deployment including its requirements and expectations with 3.78. On the other hand, the lowest mean rating was incurred in the area of "conducts initial and regular visit/inspection to ensure safety of student interns" with mean rating of 3.58. This can probably be attributed to the early cancellation of internship of students deployed for the $2^{\text {nd }}$ semester. The instructors were not able to fulfill their duties due to the constraints brought about by the pandemic. Despite this, all of the indicators registered weighted means that can be interpreted as fully implemented. This is a testament to the effectiveness of the quality management system implemented in the university. This study supports the results of the study made by Tindowen et. al., which also showed that the internship program is fully implemented within the university as long as it adheres to the guidelines set by CHED. [19] Similarly, the results emphasized the importance of orientation programs, as it is intended to assist students in making a successful transition to the work environment from the classroom and formal education setting; further, it sets the tone for student expectations and begins the process of integrating students into the work and professional culture. Successful student internship orientation leads to successful internship experience among students. [19]

Part of the role of industry partners in terms of the internship program is in collaboration with the university in designing and implementing internship plan of the students. 
As such, the industry partner is expected to sign and enter into a Memorandum of Agreement formalizing the partnership between the two parties. They are also expected to provide orientation on the various roles, responsibilities, and tasks that the students will perform competent personnel to supervise the student interns, necessary resources and facilities to achieve the internship program objectives and incentives whenever necessary. They are also expected to accomplish all necessary paperwork related to the training of student-intern. Based on the ratings provided by the interns shown in Table 8, the level of implementation of the internship program among industry partners was rated as fully implemented garnering an average weighted mean of 3.65. The students rated the indicator of "The assigned Industry Partner Supervisors are qualified and competent to handle student- interns" with a weighted mean of 3.75 which is interpreted as Fully
Implemented. This means that the agency sees to it that the most competent personnel are assigned to supervise and guide the student-intern in the duration of their stint for on-the-job training. On the other hand, the indicator of "Provides incentives to the student interns when necessary." The lowest average weighted mean with 3.36 is interpreted as implemented. There are instances when the industry partner provides incentives for the students to do extra work, such as provision of free meals and allowances. The level of implementation among industry partners aligns with the findings on level of implementation among partners conducted by Tindowen, et. al. [19] Further, the results support the findings made by Plaza and Sual which found non-compliance among host training establishments in terms of incentives like free meals and allowance while the rest of the criterion are complied with [20].

Table 7. Level of Implementation of Internship Program in PSU

\begin{tabular}{|c|c|c|c|}
\hline Indicators & $\begin{array}{l}\text { Weighted } \\
\text { Mean }\end{array}$ & $\begin{array}{l}\text { Descriptive } \\
\text { Equivalent }\end{array}$ & Rank \\
\hline $\begin{array}{l}\text { 1. Provide pre-internship orientation prior to deployment including its requirements and } \\
\text { expectations }\end{array}$ & 3.78 & Fully Implemented & 1 \\
\hline 2. Conducts initial and regular visit/inspection to ensure safety of student interns. & 3.58 & Fully Implemented & 9 \\
\hline $\begin{array}{l}\text { 3. Provides needed services and assistance through the internship instructor such as } \\
\text { recommendations in finding industry partners and free medical services and certification } \\
\text { prior to deployment }\end{array}$ & 3.72 & Fully Implemented & 2 \\
\hline 4. Forging of MOA / Internship Agreement between the University and the Industry Partner & 3.68 & Fully Implemented & 5 \\
\hline 5. Collaborates with Industry Partner to develop Internship Plan for the student interns & 3.63 & Fully Implemented & 6 \\
\hline 6. Assigned Internship Instructors are qualified and competent & 3.71 & Fully Implemented & 3 \\
\hline $\begin{array}{l}\text { 7. Internship instructors regularly conducts monitoring and assist student interns in resolving } \\
\text { problem/issues encountered }\end{array}$ & 3.62 & Fully Implemented & 7 \\
\hline $\begin{array}{l}\text { 8. Assess students' performance and behavior through appropriate evaluation instrument } \\
\text { (Internship Evaluation) }\end{array}$ & 3.69 & Fully Implemented & 4 \\
\hline $\begin{array}{l}\text { 9. Conduct of a Post OJT and Exit-Conference at the end of the internship period to validate } \\
\text { the result of internship }\end{array}$ & 3.62 & Fully Implemented & 8 \\
\hline Composite Mean & 3.67 & $\begin{array}{c}\text { Fully } \\
\text { Implemented }\end{array}$ & \\
\hline
\end{tabular}

Table 8. Level of Implementation of Internship Program in Industry Partner

\begin{tabular}{|c|c|c|c|}
\hline Indicators & Weighted Mean & $\begin{array}{l}\text { Descriptive } \\
\text { Equivalent }\end{array}$ & Rank \\
\hline 1. Collaborate with the University to design and implement the Internship Plan & 3.68 & Fully Implemented & 6.5 \\
\hline $\begin{array}{l}\text { 2. Facilitates the processing of the documents of the student intern in coordination } \\
\text { with the University }\end{array}$ & 3.68 & Fully Implemented & 6.5 \\
\hline 3. Enters into MOA/Internship Agreement with the students and University & 3.72 & Fully Implemented & 3 \\
\hline 4. Orients the student intern on the standard rules and regulations of the establishment & 3.75 & Fully Implemented & 2 \\
\hline $\begin{array}{l}\text { 5. Designs and implements the Internship schedule of activities in partnership with } \\
\text { the University }\end{array}$ & 3.62 & Fully Implemented & 10 \\
\hline $\begin{array}{l}\text { 6. Provides necessary resources/facilities needed to achieve the objectives of the } \\
\text { Student internship program }\end{array}$ & 3.63 & Fully Implemented & 9 \\
\hline 7. Provides necessary incentives to the student interns when necessary. & 3.36 & Implemented & 12 \\
\hline $\begin{array}{l}\text { 8. The assigned Industry Partner Supervisors are qualified and competent to handle } \\
\text { student- interns. }\end{array}$ & 3.75 & Fully Implemented & 1 \\
\hline $\begin{array}{l}\text { 9. Industry partner supervisors oversee students' work and in the implementation of } \\
\text { all phases of the internship }\end{array}$ & 3.68 & Fully Implemented & 5 \\
\hline 10. Accepts request for dialogue and interaction as needed & 3.61 & Fully Implemented & 11 \\
\hline $\begin{array}{l}\text { 11. Provide feedback and coaching or monitoring activities to further improve } \\
\text { performance of student-interns. }\end{array}$ & 3.70 & Fully Implemented & 4 \\
\hline 12.Issues certificates of completion for the student interns & 3.66 & Fully Implemented & 8 \\
\hline Composite Mean & 3.65 & Fully Implemented & \\
\hline
\end{tabular}


The results of the survey are revealed in Table 9 that the overall composite mean garnered by the industry partners in terms of the area of collaboration and teamwork was 3.90. This means that the student interns provided a positive feedback in terms of the industry partner's ability to foster a collaboration and teamwork within their organization. The interns agree that the people that they have worked with are an effective team with an average weighted mean of 4.01. On the other hand, despite agreeing that the team they work with have fun together, it garnered the lowest average weighted mean of 3.73. This means that despite having an agreeable sense of collaboration and teamwork, the team more focused more on achieving and completing work than having fun with each other. Though the high rating is not a cause for concern, this supports the findings made by An and Mauhay on interns in terms of collaboration and teamwork [12]

Table 9. Interns' Feedback on Industry Partner in terms of Collaboration and Teamwork

\begin{tabular}{lccc}
\hline \multicolumn{1}{c}{ Indicators } & $\begin{array}{c}\text { Weighted } \\
\text { Mean }\end{array}$ & $\begin{array}{c}\text { Descriptive } \\
\text { Equivalent }\end{array}$ & Rank \\
\hline $\begin{array}{l}\text { 1. The people with whom I } \\
\text { worked are an effective } \\
\text { team. }\end{array}$ & 4.01 & Agree & 1 \\
$\begin{array}{l}\text { 2. The people with whom I } \\
\text { worked made themselves } \\
\text { available to others to provide } \\
\text { assistance. }\end{array}$ & 3.88 & Agree & 3 \\
$\begin{array}{l}\text { 3. The person to whom I } \\
\text { reported helped me solve } \\
\text { problems. }\end{array}$ & 3.99 & Agree & 2 \\
$\begin{array}{l}\text { 4. My team took time to have } \\
\text { fun together. }\end{array}$ & 3.73 & Agree & 4 \\
\hline \multicolumn{1}{c}{ Composite Mean } & $\mathbf{3 . 9 0}$ & Agree & \\
\hline
\end{tabular}

The interns' feedback on the industry partners in terms of communication are shown in Table 10. Interpersonal communication skills are viewed as necessary life competencies, regardless of an individual's career level or status; thus, a positive feedback of student interns on the industry partner in terms of communication shows that the industry partner is effective in embodying such importance by fostering a good communication culture within. [21] The composite mean for communications was 3.72 , which means that student interns agree with the industry partner's communication strategies and competencies. This supports the findings made by An and Mauhay on interns in terms of communication. [12] The interns agree that the "communication was clear with no hidden meanings" at 3.81. However, despite a weighted mean of 3.60 indicating agreement, the indicator of "I understood what was expected of me" got the lowest. It could be possible that there is non-uniformity in terms of communicating intern's roles, responsibilities and duties between the industry partners.
Table 10. Interns' Feedback on Industry Partner in terms of Communication

\begin{tabular}{lccc}
\hline \multicolumn{1}{c}{ Indicators } & $\begin{array}{c}\text { Weighted } \\
\text { Mean }\end{array}$ & $\begin{array}{c}\text { Descriptive } \\
\text { Equivalent }\end{array}$ & Rank \\
\hline $\begin{array}{l}\text { 1. I had access to the } \\
\text { information I needed. }\end{array}$ & 3.70 & Agree & 3 \\
$\begin{array}{l}\text { 2. I understood what was } \\
\text { expected of me. }\end{array}$ & 3.60 & Agree & 4 \\
$\begin{array}{l}\text { 3. People gave feedback } \\
\text { about my work. }\end{array}$ & 3.77 & Agree & 2 \\
$\begin{array}{l}\text { 4. Communication was } \\
\text { clear with no hidden } \\
\text { meanings. }\end{array}$ & 3.81 & Agree & 1 \\
\hline \multicolumn{1}{c}{ Composite Mean } & $\mathbf{3 . 7 2}$ & Agree & \\
\hline
\end{tabular}

The feedback of the student-interns on the industry partner in terms of regard for people is presented in Table 11. Based on the results of the study, the industry partners have exhibited positive attitude towards regard for people with a mean rating of 3.95. This supports the findings of An and Mauhay on interns in terms of regard for people. [12] The indicator which incurred the highest average weighted mean was "I have a positive working relationship with my supervisor and other employees of the company" with 4.22. This means that the interns have cultivated a good working relationship with their supervisors as well as coworkers within the company. However, the statement "My development was a high priority" yielded the lowest weighted mean with 3.72. A study conducted by Liu et. al. came up with a model suggesting that interns' emotional expressions (i.e., emotional masking and emotional sharing) and social activities influence the degree to which they learn and receive mentoring from their supervisors during the internship, which further influence interns' job satisfaction, affective commitment to the internship sponsor, and career attitude. [22] This entails that the interns receive a good deal of mentoring from supervisors due to the inherent openness of the industry partners towards fostering positive relationships with the interns.

Table 11. Interns' Feedback on Industry Partner in terms of Regard for People

\begin{tabular}{lccc}
\hline \multicolumn{1}{c}{ Indicators } & $\begin{array}{c}\text { Weighted } \\
\text { Mean }\end{array}$ & $\begin{array}{c}\text { Descriptive } \\
\text { Equivalent }\end{array}$ & Rank \\
\hline $\begin{array}{l}\text { 1. People were listened to as } \\
\text { equals regardless of race, } \\
\text { gender, position, age, }\end{array}$ & 3.91 & Agree & 3 \\
education or career level. \\
$\begin{array}{l}\text { 2. People were treated } \\
\text { fairly. }\end{array}$ & 3.93 & Agree & 2 \\
$\begin{array}{l}\text { 3. I have a positive working } \\
\text { relationship with my } \\
\text { supervisor and other } \\
\text { employees of the company. }\end{array}$ & 4.22 & Agree & 1 \\
$\begin{array}{l}\text { 4. My development was a } \\
\text { high priority. }\end{array}$ & 3.72 & Agree & 4 \\
\hline \multicolumn{2}{c}{ Composite Mean } & $\mathbf{3 . 9 5}$ & Agree \\
\hline
\end{tabular}


Table 12. Interns' Feedback on Industry Partner in terms of Decision Making and Empowerment

\begin{tabular}{lccc}
\hline \multicolumn{1}{c}{ Indicators } & Weighted Mean & Descriptive Equivalent & Rank \\
\hline 1. The person to whom I reported was supportive of my decisions. & 3.06 & Neither Agree nor Disagree & 2 \\
2. I was comfortable raising issues or questions. & 2.99 & Neither Agree nor Disagree & 3 \\
3. I received regular constructive feedback on my performance & 2.83 & Neither Agree nor Disagree & 4 \\
4. I was trusted to do a good job. & 3.12 & Neither Agree nor Disagree & 1 \\
\hline \multicolumn{1}{c}{ Composite Mean } & $\mathbf{3 . 0 0}$ & Neither Agree nor Disagree \\
\hline
\end{tabular}

Table 12 presents the interns' feedback on the industry partner in terms of decision making and empowerment. According to Ramasamy, empowerment is an organizational state, where people are aligned with business direction and understand their performance boundaries, thus enabling them to take responsibility and ownership while seeking improvements, identifying the best course of action and initiating steps to satisfy customers' requirements. [23] The student interns rated the industry partners with a weighted mean of 3.00 across all indicators for decision making and empowerment. This means that the students neither agree nor disagree on the industry partner's attitude towards delegating decision-making functions and empowering interns. This contradicts the findings of An and Mauhay on interns in terms of decision making and empowerment. [12] The perceived lack of trust from supervisors and other employees was shown in terms of the indicator "I am trusted to do a good job" which got the highest mean rating of 3.12 but still being interpreted as neither Agree nor Disagree. The students rated lowest the indicator about receiving constructive feedback on performance. The indicator only garnered a mean rating of 2.83 . Usually feedback on performance is only given by the end of the internship period through the performance evaluation form for interns. Thus, it is highly encouraged that employees of industry partners proactively provide constructive criticism on a weekly basis if necessary.

The intern's feedback on industry partner in terms of work ethics is presented in Table 13. The students agree that the industry partners manifested a high level of work ethics with a weighted mean of 3.84. The students agree that the industry partner values employee satisfaction with a mean rating of 3.94. However, despite agreeing with a mean rating of 3.68 , it is less likely that the people working with the intern will take ownership for the outcomes and results. Integrity means the quality of being honest and fair; one value employers look into among their employee [12] By showing an agreeable level of work ethics to the interns, the host training establishments become credible partners in instilling the value of having a high degree of work ethics and integrity to the interns.

Table 13. Interns' Feedback on Industry Partner in terms of Work Ethics

\begin{tabular}{|c|c|c|c|}
\hline Indicators & $\begin{array}{l}\text { Weighted } \\
\text { Mean }\end{array}$ & $\begin{array}{l}\text { Descriptive } \\
\text { Equivalent }\end{array}$ & Rank \\
\hline $\begin{array}{l}\text { 1. The people with whom I } \\
\text { worked acted with integrity. }\end{array}$ & 3.90 & Agree & 2 \\
\hline $\begin{array}{l}\text { 2. The people with whom I } \\
\text { worked take ownership for } \\
\text { outcomes and results. }\end{array}$ & 3.68 & Agree & 4 \\
\hline $\begin{array}{l}\text { 3. The people with whom I } \\
\text { worked care about their } \\
\text { work. }\end{array}$ & 3.86 & Agree & 3 \\
\hline $\begin{array}{l}\text { 4. The company values } \\
\text { employee satisfaction. }\end{array}$ & 3.94 & Agree & 1 \\
\hline Composite Mean & 3.84 & Agree & \\
\hline
\end{tabular}

Table 14 presents the level of attainment of internship program objectives as perceived by the students. The level of attainment of internship programs registered an overall composite mean of 4.53 , which is very highly attained. Four out of the five indicators registered weighted means can be interpreted as very highly attained with the exemption of the objective of strengthening linkages, and interaction with industry partners which incurred a weighted mean of 4.45 is interpreted as highly attained. Among all indicators of attainment of objectives, it is in the area of improving students' interpersonal skills that effective customer relationships are needed to develop which incurred a mean rating of 4.60 . 
Table 14. Level of Attainment of Internship Program Objectives

\begin{tabular}{lccc}
\hline \multicolumn{1}{c}{ Indicators } & Weighted Mean & Descriptive Equivalent & Rank \\
\hline $\begin{array}{l}\text { 1. Provide the students the necessary knowledge and competence needed } \\
\text { in the industry }\end{array}$ & 4.52 & Very Highly Attained \\
$\begin{array}{l}\text { 2. Improve the students' interpersonal skills needed to develop effective } \\
\text { customer relationships; }\end{array}$ & 4.60 & Very Highly Attained \\
$\begin{array}{l}\text { 3. Provide students opportunities to apply business/management skills to } \\
\text { actual work setting }\end{array}$ & 4.54 & Very Highly Attained \\
$\begin{array}{l}\text { 4. Develop the life skills of the student interns including those relevant to } \\
\text { the values of professionalism and work appreciation }\end{array}$ & 4.56 & Very Highly Attained \\
5. Strengthen linkages and interaction with industry partners & 4.45 & Highly Attained \\
\hline \multicolumn{1}{c}{ Composite Mean } & $\mathbf{4 . 5 3}$ & Very Highly Attained & 5 \\
\hline
\end{tabular}

Table 15. Problems Encountered by Interns during Internship

\begin{tabular}{|c|c|c|c|}
\hline Indicators & Weighted Mean & Descriptive Equivalent & Rank \\
\hline 1. Unsupportive internship instructor & 1.22 & Not a Problem & 9 \\
\hline 2. Lack of self Confidence & 1.68 & A Problem & 1 \\
\hline 3. The training was not aligned in the field of specialization & 1.37 & Not a Problem & 4 \\
\hline 4. Distance of the Industry Partner from the school is too far & 1.50 & Not a Problem & 2 \\
\hline 5. Misunderstanding with the student trainee in the workplace & 1.47 & Not a Problem & 3 \\
\hline 6. No harmonious relationship with the Industry partner employees & 1.29 & Not a Problem & 6 \\
\hline 7. Strict training supervisor & 1.29 & Not a Problem & 5 \\
\hline 8. Sexual harassment & 1.14 & Not a Problem & 13 \\
\hline 9. Long working hours & 1.20 & Not a Problem & 11 \\
\hline 10. There is a risk of hazard/accident in the workplace & 1.22 & Not a Problem & 8 \\
\hline 11. instructions are not clearly defined & 1.24 & Not a Problem & 7 \\
\hline 12. Inadequate tools and equipment to develop student skills & 1.21 & Not a Problem & 10 \\
\hline 13. Uncooperative training supervisor & 1.15 & Not a Problem & 12 \\
\hline Composite Mean & 1.31 & Not a Problen & \\
\hline
\end{tabular}

The seriousness of problems encountered by interns during internship is presented in Table 15. The problems incurred an overall composite mean of 1.31 which translates to not a problem. While the severity of the problem varies from student-to-student, it shows that the existence of problems exists among a small group of student interns as supported by the mean rating incurred. Among the listed problems, the students rated lack of self-confidence, distance of the Industry Partner from the school is too far, and misunderstanding with the student trainee in the workplace which incurred weighted means of $1.68,1.50$ and 1.47 respectively. Among the three, the lack of self-confidence was determined to be a problem impacting the interns. This supports the findings made by Hacla which shows that lack of self-confidence as a problem occurring among interns. This should be of particular concern as self-confidence is highly related to an intern's personal employability skills. [24] However, this study points that distance is not a problem; it also supports the results of Hacla's study pointing out that the distance of the industry partner is a problem moderately affecting the interns. [11] On the other hand, sexual harassment, uncooperative training supervisor, and long working hours incurred the lowest mean rating which means that while the problems exist, they are isolated and manageable. The said problems incurred mean ratings of $1.14,1.15$, and 1.20 respectively.

Table 16 presents the results of the correlation analysis, which is conducted to determine the relationship between the level of implementation of internship program in industry partner, the students' feedback about the industry partner, the attainment of objectives, and the seriousness of problems encountered.

The study revealed a positive relationship between the level of implementation and four out of five areas of concern in terms of students' feedback on the industry partners namely collaboration and teamwork, people indicators, communication, and work ethics. The p-value was computed to be less than 0.01 indicating that the association between the variables was strong. The correlation coefficients computed to be at $0.602,0.607$, 0.608 , and 0.573 respectively indicate that the relationship is moderate. The increase in the level of implementation of the internship program in the industry partner corresponds to an increase in the students' feedback on said areas. However, the level of implementation found an inverse relationship with the area of decision making and empowerment. It shows a negative relationship, albeit a weak one $(\mathrm{r}=-0.198, \mathrm{p}<0.05)$. Following the assertion made by Kasli and Ilban on the impact of problems encountered on attitude of interns towards jobs related to their field of study, it is more likely that the graduates of the Business Administration program will find a job in line with their course in the future due to the positive relationship between implementation and the low level of seriousness of problems encountered during their internship [13] 
Table 16. Relationship between Level of Implementation of Internship Program in Industry Partner, Student Interns' Feedback, Attainment of Program Objectives, and the Seriousness of Problems Encountered

\begin{tabular}{|c|c|c|c|c|c|c|c|c|c|}
\hline & & \multirow[b]{2}{*}{$\begin{array}{c}\text { Level of } \\
\text { Implementation }\end{array}$} & \multicolumn{5}{|c|}{ Student Interns' Feedback } & \multirow[b]{2}{*}{$\begin{array}{l}\text { Attainment of } \\
\text { Objectives }\end{array}$} & \multirow[b]{2}{*}{$\begin{array}{c}\text { Problems } \\
\text { Encountered }\end{array}$} \\
\hline & & & $\begin{array}{l}\text { Collaboration } \\
\text { and Team Work }\end{array}$ & $\begin{array}{l}\text { Communication } \\
\text { Indicators }\end{array}$ & $\begin{array}{l}\text { People } \\
\text { Indicators }\end{array}$ & $\begin{array}{c}\text { Decision Making } \\
\text { and } \\
\text { Empowerment }\end{array}$ & Work Ethics & & \\
\hline \multirow{6}{*}{$\begin{array}{c}\text { Student } \\
\text { Interns' } \\
\text { Feedback }\end{array}$} & of Implementation & - & & & & & & & \\
\hline & $\begin{array}{c}\text { Collaboration and } \\
\text { Teamwork }\end{array}$ & $0.602 * *$ & - & & & & & & \\
\hline & Communication Indicators & $0.607 * *$ & $0.783^{* *}$ & - & & & & & \\
\hline & People Indicators & $0.608^{* *}$ & $0.742^{* *}$ & $0.807^{* *}$ & - & & & & \\
\hline & $\begin{array}{c}\text { Decision Making and } \\
\text { Empowerment }\end{array}$ & $-0.191 *$ & -0.141 & -0.168 & -0.143 & - & & & \\
\hline & Work Ethics & $0.573^{* *}$ & $0.738^{* *}$ & $0.735^{* *}$ & $0.817^{* *}$ & $-0.225^{*}$ & - & & \\
\hline \multicolumn{2}{|c|}{ Attainment of Objectives } & $0.596^{* *}$ & $0.571^{* *}$ & $0.599 * *$ & $0.650^{* *}$ & -0.027 & $0.629^{* *}$ & - & \\
\hline \multicolumn{2}{|c|}{ Problems Encountered } & $-0.255^{* *}$ & -0.082 & -0.137 & -0.176 & 0.105 & $-0.206^{*}$ & $-0.194 *$ & - \\
\hline
\end{tabular}

**. Correlation is significant at the 0.01 level (2-tailed).

*. Correlation is significant at the 0.05 level (2-tailed). 
The level of implementation was also found to have a statistically significant relationship with the attainment of internship objectives with $\mathrm{p}<0.01$. The relationship was found moderately positive with $\mathrm{r}=0.596$. This indicates that an increase in the level of implementation of the internship program on the industry partner constitutes an increase in the level of attainment of internship objectives.

Further, the level of implementation was found to have a statistically significant relationship with the seriousness of problems encountered with $\mathrm{p}<0.01$. The relationship was determined to be a weak inverse one with $r=-0.255$. The inverse relationship indicates that the higher the level of implementation of internship program, the less serious the problems interns encountered

\section{Limitations of the Study}

The respondents of the study are the Business Administration students of Pangasinan State University Lingayen Campus. The study can be expanded and replicated across other programs which offer practicum. It is also advised to expand the study to include students from other campuses of Pangasinan State University for more robust findings and conclusions. The profile variables of the students can be expanded to include program, campus, and other categories yet to be determined. Industry partner's profile can also be improved upon to include the size of the organization.

\section{Conclusions and Recommendation}

Three-quarters of the Business Administration students are female and all live within the Province of Pangasinan. The industry partners are all located in Northern Luzon and most of them are government institutions. The level of implementation of the internship program within PSU is fully implemented. It is also the same within the industry partner. However, in terms of providing incentives, it was found that it is not at the same level as the other indicators of implementation. The industry partners support the interns in terms of collaboration and teamwork, regard for people, communication and work ethics. The students found to be on the fence in terms of decision making and empowerment within industry partners which show that industry partners are somewhat cautious about giving interns the full discretion when it comes to deciding on important work matters. From the perspective of the interns, the objectives of the internship program are very highly attained by the time of their completion. The most common problems encountered by the interns are on their lack of self-confidence, the distance of the industry partner from their residence, and harmonious relationship with fellow intern. The level of implementation of internship program within the industry partner is related to the students' feedback on industry partners, attainment of internship objectives and problems encountered. It shows that the level of implementation enhances the perception of the students of industry partner with the exception of the area of decision making and empowerment. A stronger implementation of the internship program also contributes to the realization of internship objectives as well as minimization of the problems encountered.

A review of the memorandum of agreement may be necessary to improve the role of the industry partner in providing incentives and allowances for interns during training. The institution may also consult with industry partners in discussing the expansion of autonomy offered to students to improve their competency in terms of decision making and empowerment. The program can formally identify the students who have issues with regards to distance of industry partner and ensure that they are deployed to nearer companies. Also, as part of the orientation, personality development courses can be introduced during the pre-internship training to boost the student interns' self-confidence. Team building activities can also be conducted to strengthen the relationship between interns and later minimize the conflicts arising between them during the internship period. To expand the study, future researchers may include other programs which offer practicum courses for more robust study findings.

\section{Acknowledgments}

The researcher would like extend her gratitude to the President of Pangasinan State University, Dr. Dexter R. Buted, the Vice President for Research and Extension, Dr. Paulo V. Cenas, the Executive Director of the PSU Lingayen Campus, Dr. Lorna G. Urbiztondo, the College Dean of Business and Public Administration, Dr. Randy Joy M. Ventayen, and the faculty members of the Business Administration program. Above all, I would like to dedicate this study to family, my husband Tony, and my dear son, Luke for inspiring me and making me feel loved each and every single day.

\section{REFERENCES}

[1] Walo, Maree. "Assessing the contribution of internship in developing Australian tourism and hospitality students' management competencies." International Journal of Work-Integrated Learning 2, no. 2 (2001): 12.

[2] Commission on Higher Education. (2017, July 19). CMO NO. 104 s. 2017. Retrieved from www.ched.gov.ph: http://www.ched.gov.ph

[3] Gault, J., Leach, E., \& Duey, M. (2010). Effects of Business Internships on Job Marketability: The Employers' Perspective. Education + Training, 52(1):76-88.

[4] Weible, R. (2009). Are universities reaping the available 
benefits internship programs offer?. Journal of education for business, 85(2), 59-63.

[5] Bell, B., \& Schmidt, C. (1996). Field practicums: What influence on graduate careers? In A. Yarrow, J. Millwater, S. DeVries, \& D. Creedy (Eds.), Practical experiences in professional education: Research monograph (pp.123-134). Brisbane, Australia: Queensland University of Technology Publications and Printery.

[6] Karen Joy A. Catacutan, Fe Rose-Anne Maramag, Mary Ann Bartolome, Rose Marie Hiquiana, Marie Jean Mendezabal (2020). Employability Study of the Business Administration Graduates of Catholic Educational Institution. Universal Journal of Educational Research, 8(1), 156 - 161. DOI: 10.13189/ujer.2020.080119.

[7] Bernarte, R. P. (2014). Academe-Industry Partnership in the Philippines: Nature, Benefits and Problems. Asia Pacific Higher Education Research Journal (APHERJ), 1(1).

[8] Smith L. \& Rees L. (2002). University-Industry Collaboration: A Community Approach. Retrieve from: www.crn.net

[9] Chavez, N. H. (2014). Developing Students' Competencies and Academic Performance through Academe-Industry Partnership. Asia Pacific Journal of Education, Arts and Sciences, 1(5), 1-10.

[10] Coco, M. (2000). Internships: A try before you buy arrangement. SAM Advanced Management Journal, 65(2), 41.

[11] Hacla, R.P. (2016). Skills Acquired by the Electrical Engineering Students of Pangasinan State University on their On-the-Job Training.

[12] An, I. L., \& Mauhay, R. C. A. (2016). Interns' Feedback on Industry Partners: Inputs for an Enhanced Internship Program. Asia Pacific Journal of Education, Arts and Sciences, 3(2), 74-81.

[13] Kasli, M., \& Ilban, M. O. (2013). The Influence of Problems Faced during Internships on Interns' Views of Their Profession and Their Intention to Work in the Tourism Industry. Eurasian Journal of Educational Research, 52,
$79-95$.

[14] Pring-Valdez, A. (2012). Curriculum Model for Medical Technology: Lessons from International Benchmarking. Online Submission, 3, 292-301.

[15] PRPIO PSU. (2017, February 13). PSU is now ISO 9001:2015 Certified. Retrieved August 01, 2020, from https://www.psu.edu.ph/psu-is-now-iso-90012015-certified/

[16] Commission on Higher Education. (n.d.). CMO NO. $23 \mathrm{~s}$. 2009. Retrieved from https://ched.gov.ph/cmo-23-s-2009/

[17] Porter, M. E. (2001). The value chain and competitive advantage. Understanding Business Processes, 50-66.

[18] Tindowen, D. J., Bangi, J., \& Parallag Jr, C. (2019). Pre-Service Teachers' Evaluation on their Student Internship Program. International Journal of Learning, Teaching and Educational Research, 18(10), 279-291.

[19] Rothman, M. (2007). Lessons learned: Advice to employers from interns. Journal of Education for business, 82(3), 140-144.

[20] Plaza II, O. N., \& Sual, R. J. (2017). Student Internship Program of the Philippines and 21 st Century Competencies: Basis for the Improvement of On-the-Job Training. Liceo Journal of Higher Education Research, 13(1).

[21] Quinn, R. E., Faerman, S. R., Thompson, M. P., \& McGrath, M. (2003). Becoming a master manager: A competency framework. John Wiley \& Sons.

[22] Liu, Y., Xu, J., \& Weitz, B. A. (2011). The role of emotional expression and mentoring in internship learning. Academy of Management Learning \& Education, 10(1), 94-110.

[23] Ramasamy, S. (2005). Total Quality Management”. Tata Mc Graw Hill. New Delhi. India.

[24] Mohd Hazwan Mohd Puad, Hazeem Mohamad Desa (2020). Dissecting Perceptions of New Graduates on Work Orientation and Self-Confidence in Employability Skills Training Program. Universal Journal of Educational Research, 8(1A), 70 - 75. DOI: 10.13189/ujer.2020.081310 